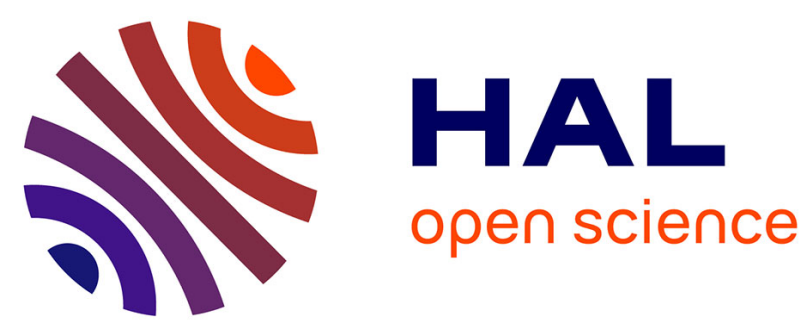

\title{
Humusica 2, article 12: Aqueous humipedons - Tidal and subtidal humus systems and forms
}

Augusto Zanella, Chiara Ferronato, Maria de Nobili, Gilmo Vianello, Livia

Vittori Antisari, Jean-François Ponge, Rein de Waal, Bas van Delft, Andrea

Vacca

\section{To cite this version:}

Augusto Zanella, Chiara Ferronato, Maria de Nobili, Gilmo Vianello, Livia Vittori Antisari, et al.. Humusica 2, article 12: Aqueous humipedons - Tidal and subtidal humus systems and forms. Applied Soil Ecology, 2018, 122 (Part 2), pp.170-180. 10.1016/j.apsoil.2017.05.022 . hal-01667378

\section{HAL Id: hal-01667378 https://hal.science/hal-01667378}

Submitted on 19 Dec 2017

HAL is a multi-disciplinary open access archive for the deposit and dissemination of scientific research documents, whether they are published or not. The documents may come from teaching and research institutions in France or abroad, or from public or private research centers.
L'archive ouverte pluridisciplinaire HAL, est destinée au dépôt et à la diffusion de documents scientifiques de niveau recherche, publiés ou non, émanant des établissements d'enseignement et de recherche français ou étrangers, des laboratoires publics ou privés. 


\title{
Humusica 2, article 12: Aqueous humipedons - Tidal and subtidal humus systems and forms
}

\author{
Augusto Zanella ${ }^{a}$, Chiara Ferronato ${ }^{b,}{ }^{*}$, Maria De Nobilic, Gilmo Vianello ${ }^{b}$, Livia Vittori Antisari ${ }^{b}$, Jean- \\ François Ponge ${ }^{d}$, Rein De Waal ${ }^{e}$, Bas Van Delft ${ }^{e}$, Andrea Vacca ${ }^{f}$ \\ ${ }^{a}$ University of Padua, Italy \\ ${ }^{\mathrm{b}}$ University of Bologna, Italy \\ ${ }^{\mathrm{c}}$ University of Udine, Italy \\ ${ }^{\mathrm{d}}$ Muséum National d'Histoire Naturelle, Paris, France \\ ${ }^{\mathrm{e}}$ University of Wageningen, The Netherlands \\ ${ }^{\mathrm{f}}$ University of Cagliari, Italy
}

\section{ABSTRACT}

Soils formed in tidal and subtidal environments often do not show sufficient accumulation of undecomposed plant tissues to be classified as Histosols. In this article we present a first attempt of morpho-functional classification of aquatic humus, a revision of the terminology and of the diagnostic features employed by pedologists in the description of aqueous and submerged soils, and we finally suggest some criteria to be used during field investigations. According to the proposed criteria, Redoxi, Reductitidal, and Subtidal humus forms can be distinguished in aquatic systems, avoiding any possible confusion with Histic, Epihisto, Hydro and Para Anaero/Archaeo or Crusto humus forms. The article concludes with some examples of classification, including prefixes for detailing particular intergrades with the other groups of humipedons and with the discussion of the contribution of algae and seagrasses to the formation of Crusto forms.

\footnotetext{
${ }^{*}$ Corresponding author.

E-mail addresses: augusto.zanella@unipd.it (A. Zanella), chiara.ferronato2@unibo.it (C. Ferronato), maria.denobili@uniud.it (M. De Nobili), gilmo.vianello@unibo.it (G. Vianello), livia.vittori@unibo.it (L. Vittori Antisari), ponge@mnhn.fr (J.-F. Ponge), rein.dewaal@wur.nl (R. De Waal), bas.vandelft@wur.nl (B. Van Delft), avacca@unica.it (A. Vacca).
} 


\section{Content}

Chapter essence: in tidal environments soils are differently affected by water saturation. The soil classification of subaqueous pedons has been recently introduced in the international soil classification systems but much of it is still unclear, undescribed and misunderstood. This chapter gives an overview of the humus forms found in tidal hydric and subaqueous soils.

Functional lecture: basic concepts of hydric and subaqueous classification (1) and examples of pedogenetic humus forms in hydric and subaqueous soils (3).

\section{What are tidal and subaqueous soils?}

The concept of subaqueous soils is relatively new in soil science, and it has soon triggered a strong debate between sediment and soil scientists (Kristensen and Rabenhorst, 2015). Traditionally, in fact, subaqueous substrates have always been "simply" considered as deposits of either allochthonous (terrigenous) and autochthonous (often biological) material (Burdige, 2006), that accumulate over time through particle sedimentation from the overlying water column. The colonization by different kinds of rooted vegetation in tidal and subtidal areas, the existence of layer differentiation linked to several physicochemical and biological processes, and the occurrence of processes of soil formation similar to those observed in terrestrial environments, supported the possibility to rank some aquatic substrates located in the intertidal and shallow subtidal and tidal areas (Fig. 1), as proper "subaqueous soils" (Demas and Rabenhorst, 2001).

According to this assumption, in many coastal environments such as estuaries, coastal wetlands and lagoons, soils may develop under permanently submerged conditions (subaqueous soils, Demas and Rabenhorst, 2001), or by partial or provisional water saturation conditions (hydromorphic or hydric soils, Richardson et al., 2001).

Hydric soils are characterized by the continuous wetting and drying of soil horizons, and by the alternation of aerobic and anaerobic processes which strongly affect soil pedogenesis (Demas and Rabenhorst, 2001).

On the other hand, permanent submergence allows a different mechanism of interstitial water and oxygen diffusion within the soil, and in the last decades researchers demonstrated that subaqueous substrates can be subjected to pedogenic processes similar to those that occur in subaerial soils (e.g. addition of organic matter through root growth) but also including unique subaqueous pedogenic processes (e.g. addition of carbonates and hardening of the surface through oyster reef growth) (Demas et al., 1996).

The interest in subaqueous and hydric soils, mostly focussed on coastal zones, derives from a social and economic reason: societies has always developed next to water reservoirs and still nowadays, almost $75 \%$ of the world population lives in proximity of coastal areas (within $100 \mathrm{~km}$, UNEP, 2006; McGranahan et al., 2007), among which 10\% lives in the Low Elevation Coastal Zone (less than $10 \mathrm{~m}$ a.s.I., McGranahan et al., 2007). Moreover, estuaries, marshes, lagoons and shallow 
coastal waters cover approximately only $1-2 \%$ of the marine area but support $20 \%$ of marine primary production, providing employment for 38 million people as fishermen, with a further 162 million people indirectly involved in fishery industry (UNEP, 2006). However, most of the aquaculture carried out in the world today is done without proper soil surveys, and the maps of subaqueous soils could be of great interest for the placement of shellfish aquaculture (Rabenhorst and Stolt, 2012).

The economic benefits provided by coastal management include not only fishery or aquaculture (which is actually an expanding sector), or tourism. Beaches, dunes, saltmarshes, estuaries, and mudflats provide a variety of ecosystem services: they play an important role in the mitigation of water contamination, regulation of geo-chemical cycles of nutrients and trace metals (Ponnamperuma, 1972; Homann and Grigal, 1996; Gedan et al., 2010; De Groot et al., 2012), and in the preservation of important zoocenoses and biocenoses (Silvestri et al., 2005; Bradley and Stolt, 2006; Erich and Drohan, 2012).

All these services are often threatened by overexploitation of the coasts, together with rising of the sea level (IPCC AR4 SYR, 2007), which promotes erosion processes, reduction and degradation of coastal habitats (Lotze et al., 2006; Halpern et al., 2008; Moretti et al., 2015). The extension of degradation processes in wetland and coastal saltmarshes, due to both natural environmental changes and anthropic stressors is bringing to the decline of these zones by $60 \%$ in Europe and by $50 \%$ in the USA (Kennish, 2001; Lotze et al., 2006; Wong et al., 2015).

Scientists, by conducting researches on landscape, ecosystem, community and population, can give a very important contribution to the creation of a theoretical and practical framework for monitoring and managing the land (Ewel et al., 2001).

\section{The evolution of SAS classification}

As summarized in Ferronato (2015), the first definition of soil introduced by the Russian school led by Vasily Dokuchaev (1846-1903) described soils as independent natural bodies with a unique morphology resulting from a unique combination of climate, living matter, earthy parent materials, relief, and age of landforms (Gedroiz, 1927). In the following years, soil genesis was better defined by the work of Hans Jenny (1899-1992), entitled "Factors of Soil Formation". In this treatise, he stated the famous state factors equation of soil-forming and development:

Soil $(S)=f(C, O, R, P, T)(1)$

According to this model, soil derives from the interaction of several factors, such as climatic conditions $(C)$, biological activity of soil organisms $(O)$, topographical relief $(R)$, nature of the parent material $(P)$, and time $(T)$. These factors act on soils in four ways. Additions can be made to the soil profile, materials can be removed, substances can be transformed in the soil, and they can also be translocated through the soil (Simonson, 1959).

In the last decades the concept that sediments in shallow water environments are capable of supporting rooted plants, and undergo transformation and horizon differentiation, has led soil 
scientists to consider the hypothesis of a subaqueous pedogenetic process, which occur similarly to terrestrial ones (Demas and Rabenhorst, 1999; Ellis et al., 2002). On subaqueous substrates, in fact, as reported in Ferronato (2015) it has been demonstrated that the presence of buried horizons, the accumulation of biogenic $\mathrm{CaCO}_{3}$, the presence of benthic fauna and of organic components, can be considered common pedogenic additions (Barko et al., 1991; Demas and Rabenhorst, 1999a). Similarly, to some subaerial pedons, pedogenetic losses of nutrients can be observed though the distribution of organic carbon, which usually decreases with depth along the soil profile. In both systems, in fact, the mineralization of organic carbon occurs mostly thanks to microbial metabolism, even if different degradation processes can be recognized (Roden, 2004; Vodyanitskii and Shoba, 2014).

Microbial biomass, enzyme production and metabolic pathways strongly contribute to different processes that promote stabilization through the formation of soil structure or anoxic transformations along the soil profile (Demas and Rabenhorst, 1999; Cocco et al., 2015). Examples of transfers include accumulations and depletions of iron and manganese species, diffusion and bioturbation from shellfish and worms (Fanning and Fanning, 1989), which promote soil horizon differentiation (Fenchel and Riedl, 1970).

Consequently to these observations, some American soil scientists (e.g. George Demas, Martin Rabenhorst, Michael P. Bradley, Mark H. Stolt, Emilie Erich, Michael Payne, Danielle Balduff) have proposed a new state factors equation to describe the formation and development of subaqueous soils:

Subaqueous Soil (SAS) $=f(C, O, B, F, P, T, W, E)(2)$

In this model, similarly to terrestrial soils, they recognize the importance of considering temperature conditions $(\mathrm{C})$, biological activity of soil organisms $(\mathrm{O})$, nature of the parent material $(\mathrm{P})$, and time $(T)$. In addition, for subaqueous soil formation, they stress the important role of bathymetry (B) and of the flow regime (F), the essential role of water characteristics (W) and of catastrophic events (E) (Demas and Rabenhorst, 2001).

Pedological investigations on subaqueous substrates have finally led to an extension of the definition of the soil upper limit in the USDA Soil Taxonomy (Soil Survey Staff, 2010). Since 2010, in fact, the $11^{\text {th }}$ approximation of the Soil Taxonomy has included the concept of subaqueous soils (SASs) as pedons covered by up to $2.5 \mathrm{~m}$ of water with a positive water potential on the soil surface for more than $21 \mathrm{~h}$ each day in all years (Soil Survey Staff, 2010).

Subaqueous soils were therefore introduced into the USDA soil classification system, and at present they can be accurately classified in two new suborders, Wassents and Wassists.

Subaqueous Histosols (Wassists) are characterized by electrical conductivity $<0.2 \mathrm{dS} / \mathrm{m}$ (Frasiwassists) or the presence of sulfidic materials for $15 \mathrm{~cm}$ within $50 \mathrm{~cm}$ of the soil (Sulfiwassists) or by the absence of any other specific features (Haplowassists). Subgroups are further recognized based on the degree of decomposition (Fibric, Sapric), deep sulfidic materials (Sulfic) and absence of other specific features (Typic).

Subaqueous Entisols (Wassents) are characterized by sweet water environment (Frasiwassents), sandy or loamy sandy texture (Psammowassents) or finer texture and fluidity 
(Hydrowassents), presence of sulfidic materials (Sulfiwassents), or irregular distribution of texture and organic carbon (Fluviwassents) or by the absence of any other specific features (Haplowassents). Sulfic, Lithic, Thapto-Histic, Aeric, Hydric, Psammentic, Fluventic, Grossic, Haplic and Typic subgroups are further recognized (Fig. 2).

On the other hand, the World Reference Base for Soil Resources (IUSS Working Group WRB, 2006) has recently introduced the qualifier Tidalic for describing pedons flooded by tidewater at mean high tide but not covered by water at mean low tide. The Subaquatic qualifier is used for permanently submerged pedons under water table not deeper than $200 \mathrm{~cm}$, or Stagnic, for pedons at least temporarily saturated with surface water (or saturated in the past, if now drained) for a period long enough that reducing conditions occur.

The new qualifiers (i.e., Tidalic and Subaquatic) can be ascribed to most of the soil groups (e.g. Cryosols, Arenosols, Fluvisols, Gleysols, Histosols, Leptosols, Solonchaks and Technosols) but to our knowledge, their usage is still limited (Fig. 2).

\section{Pedogenetic features in hydric and subaqueous soils of tidal environments}

With the aim of investigating hydric and subaqueous soil systems in tidal areas, the pedological approach uses to trace some morphological and micro-topographical transects and to describe any changes of morphological and physicochemical features from the higher to the lower part of the soil catena (Ferronato et al., 2016; Vittori Antisari et al., 2016). This approach, supported by literature data, takes into account changes in vegetation patterns which evolve differently within a few meters in a tidal environment (Fig. 3), and allows identifying the key variables that drive pedogenetic processes and soil evolution as function of the different contributions of marine vs riverine sediment depositions, different hydrogeological backgrounds, different morphologies of the coast and different intrinsic conditions of the soil.

\subsection{Redoximorphic features and sulphidization processes}

Matrix colour variability in hydromorphic environments results from the alternation of wet/dry cycles of soil horizons which induce the reduction, translocation and/or oxidation of iron and manganese oxides (Schaetzl and Anderson, 2005). Moreover, the pedogenetic horizons affected by aeration during low tide generally display the presence of redoximorphic features, characterized by reddish concentration and/or black nodules, masses of films due to the effect of Fe and Mn oxidation and reduction, or to the decomposition of organic materials (Fig. 4).

The study of the Munsell colour variation in the hydric and subaqueous soils can be used as a very fast and field indicator of the soil hydromorphy. Figure 5 displays a schematic representation of the presence of redoximorphic features along the soil cores (a) and of the soil matrix colour (b), observed in some saltmarshes transects in northern Adriatic sea, studied by Ferronato et al. (2015). 
The colour of the soil matrix ranges from brownish (10YR) to yellowish (2.5Y) and grey to black colours (generally $10 \mathrm{Y}, 5 \mathrm{GY}$ and $\mathrm{N}$ ), according to the intensity of gleyfication processes due to prolonged water saturation of the soil, while redoximorphic features, mostly appeared in the tidal rage between the high and the low tide.

The development of redoximorphic features is often associated to the presence of plant roots, which strongly contribute to diffuse oxygen and prevent anoxic conditions, and are often embedded in films of iron oxides (Génin et al., 1998; Richardson et al., 2001). Some examples of these features are shown in Figure 6. Fine roots and organic fragments at different decomposition stages are commonly detected in these pedons, due to the continuous effect of sediment transportation and erosion by water, and to the low decomposition rate of organic matter under anoxic conditions (Reddy and DeLaume, 2008). The contribution of microorganisms and other biological forms to the formation of these redoximorphic pedogenetic features has not been sufficiently investigated by the scientific community, but their fundamental role in characterizing the soil development is testified by the long-term persistence of residual reddish mottled forms in buried submerged horizons.

In fresh water, brackish and salt marsh soils, sulphur is reduced (Krairapanond et al., 1992; Kao et al., 2004), assuming very dark, gleyic, or bluish colours. In these conditions, the compounds formed by reduced $\mathrm{S}$ can react with free $\mathrm{Fe}^{2+}$, inducing sulphidization processes (Fanning and Fanning, 1989; Demas and Rabenhorst, 1999) and thus developing sulfidic horizons (Ferronato et al., 2016). This process, which is much more pronounced in tidal environments due to the large concentration of sulphate ions in marine water, is usually accompanied by the decrease of the organic carbon/S index, due to the increase of sulphide concentration with respect to organic carbon concentration (Ivanov et al., 1989). Changes in the hydric regime and soil surface exposure to atmospheric oxygen may allow the oxidation of reduced $\mathrm{S}$ compounds to other compounds such as $\mathrm{H}_{2} \mathrm{SO}_{4}, \mathrm{SO}_{2}$, dimethyl sulfoxide-DMSO and dimethyl sulphide-DMS, which induce $\mathrm{pH}$ lowering and soil acidification in a process known as sulfurization, forming active acid sulphate soils (Dent and Pons, 1995; Bradley and Stolt, 2003).

A strong accumulation of sulphides was also observed in saltmarsh soils of the northern Adriatic Sea by Vittori Antisari et al. (2016); however, in these soils, lowering of pH was not observed due to the relatively high content of carbonated sands in the area, which acts as a powerful chemical buffer (Fossing and Jorgensen, 1989; Descostes et al., 2002; Vittori Antisari et al., 2016). It is this balance between acid production and buffering/neutralization of $\mathrm{pH}$ changes that makes the identification and classification of acid sulphate soils particularly difficult, and particularly interesting to clear out for different purposes. At present, in fact, Soil Taxonomy does not provide a way to recognize soils that have accumulated mineral iron sulphide phases, but which also contain substantial carbonates that would neutralize the acidity generated during sulphur oxidation (Vittori Antisari et al., 2016).

During spring when sygyzial tides cause prolonged submergence, algae can grow at the soil surface or in the overlying water: upon drying, their death and deposition at the soil surface result in the formation of relatively thin (a few millimetres) but dense films that form a sealing mat at the soil surface. The formation of algal mats and of biofilms of algal or bacterial cells has important effects on the aeration of the underneath soil, as it can block the diffusion of oxygen and promote severe 
anoxic conditions at only a few millimetres below the soil surface even when the soil is no longer submerged. Under these conditions accumulation of sulphides can occur at the soil surface itself, right under the thin, but dense layer of fibrous material, as testified by the dark grey-black colour and typical smell of rotten eggs of the soil. This phenomenon is often accompanied by the formation of a layer with a lamellar soil structure (Fig. 7).

\subsection{Organic matter features}

Organic matter decomposition under anoxic conditions is hindered due to energetic constraints, favouring the accumulation of organic $\mathrm{C}$ under the form of both recognizable organic remains and humic components. The study of organic matter accumulation in hydric and subaqueous systems is more complex than in terrestrial systems and has to take into account the different allocthonous and autocthonous sources of carbon involved. For example, carbon inputs can be found as suspended or dissolved particulate matter/carbon transported by the water flow, as terrestrial organic matter deposits flowed onto submerged areas, or as in situ production of organic compounds. At the same time we must consider different humification rates, which vary not only depending on type of material, but also on location of the soil, and, last but not least, on interactions occurring between minerals and reduced $\mathrm{S}$ forms. Zoological activities, both by arthropods and annelids, may be intense in these soils and contribute not only to the fragmentation and burial of organic residues and humic components (Figs. 8 and 9), but also to the diffusion of oxygen along burrows (Fig. 10)

Organic carbon distribution and humification in hydric and subaqueous soils is another interesting issue in this kind of studies. These systems, in fact, act as important $\mathrm{C}$ sinks (Reddy and DeLaume, 2008), because of the presence of a shorter life cycle of the vegetation that colonizes these areas (and a consequent larger amount of biomass deposited on the soil surface every year), the continuous supply of dissolved or particulate organic $\mathrm{C}$ from the water flow, and the slower degradation of the organic matter under reducing conditions. The organic carbon content, however is not sufficient to classify these soils as organic soils and their humus forms are different from the better known Histo forms. Lignin decomposition is virtually absent under anoxic conditions, in both Aqueous and Histo forms. At the same time, however, the input of lignified tissues is probably much lower in Aqueous systems: organic matter of algal origin, much richer in cellulose and mucilages of different composition, is also regularly deposited at the soil surface. This is probably one of the causes for the frequent lack of Histo horizons and of Histo forms in these soils.

In saltmarsh soils, in fact, surface accumulation of litter may also derive from the deposition of algal materials, either transported by tides and storms or formed in situ during periods of submergence. These materials become very light upon drying and if not cemented by salts or clay their fragments can further be scattered by the action of winds.

Much is still unknown about the Aquatic humus forms and processes in tidal and subaquatic soils. In fact, not only very few studies have been carried out so far on their characterization, but also 
studies of the influence of the different environmental processes acting on substrate stabilization are lacking.

Information on factors that regulate colonization by plants and development of different plant communities in tidal environments is also scarce and incomplete, due to the complexity of these systems (Silvestri et al., 2005). Length of submergence periods and salinity are certainly the main factors, but they explain only a part of the great variability observed in these environments.

Many authors focused on the characterization of labile organic carbon in hydromorphic and subaqueous soils (Dodla et al., 2012), or on the source and distribution of sedimentary organic carbon in subaquatic substrates (Goñi et al., 2003) but at present very few works investigated the origin and degradation of these materials, which may have been both carried from terrestrial systems by water and accumulated by sedimentary processes or originated by in situ deposition and degradation processes. These issues represent a very interesting focus for future research on this topic.

Santín et al. (2009), for example, studied the composition of the humic substances in hydromorphic and subaqueous soils under Spartina spp. cover and observed a low humification process characterized by a high portion of non-polar aliphatic constituents and a low degree of aromaticity. In their work they also discussed the possible contribution of different aquatic and terrestrial organisms. Therefore, humus studies in these soils have to take into account a number of environmental, edaphic, geo-morphological and timely aspects, which made more difficult and complex a correct approach to the problem. Moreover, the novelty of this topic and the lack of proper literature information, make these studies even more pioneer.

\subsection{Temporary humus forms, the example of Posidonia oceanica in the Mediterranean}

Posidonia oceanica (Fig. 11) is the most abundant and well-studied seagrass in the Mediterranean basin (Larkum et al., 2006; Boudouresque et al., 2012). Following winter storms, detached leaves, rhizomes and reproductive material of $P$. oceanica are transported to beaches, where they accumulate and form considerable deposits (Balestri et al., 2006, 2011; Diaz-Almela et al., 2006).

The beach-cast wrack from $P$. oceanica is a critical nutrient source and nursery for coastal fauna (Colombini and Chelazzi, 2003; Colombini et al., 2009; Ince et al., 2007) and is important for dune plant species as well (Brambilla et al., 1982; Mossa et al., 1984, 2000). In fact, these deposits contribute to the nitrogen supply of the coastal dune ecosystem, influencing a number of plant species at different stages life cycle (Cardona and García, 2008; Del Vecchio et al., 2013). A recent study, relying on a database of 572 vegetation surveys distributed across the island of Sardinia (Del Vecchio et al., 2017), found that beaches which receive high amounts of $P$. oceanica wrack have considerably greater vegetation cover ( $10 \%$ on average) than those with fewer deposits. The positive relationship between beach-cast wrack and vegetation cover was especially strong in nearshore plant communities, becoming progressively weaker along the habitat zonation. A similar pattern was found 
for species richness: beaches with high levels of accumulated wrack had more diverse drift line and foredune plant communities, while habitats further away from the shoreline were unaffected.

It is generally assumed that beach-cast wrack from $P$. oceanica plays an important role in the shore morphodynamics with a positive impact on shore stability (Boudouresque and Jeudy de Grissac, 1983; Chessa et al., 2000; Servera et al., 2002; De Falco et al., 2008). The deposition of beach-cast wrack during autumn could influence the interaction between waves and beach profile resulting in a reduction of sediment transport (McLachlan et al., 1985). Furthermore, the beach-cast wrack acts as a sediment trap (Roig et al., 2006; De Falco et al., 2008; Defeo et al., 2009).

\section{Proposal of aqueous humus systems and forms classification}

Since they are involved in food production and in costal or lagoon ecosystems protection and restoration, aqueous humus systems are very important. The following paragraph is a first attempt of a morphofunctional classification of aqueous humus, and would be just a starting draft that can be modified and improved at any moment with new data and by contacting the authors.

\subsection{Aqueous diagnostic horizons}

Organic horizons $\mathrm{OL}=$ anaOL. Layer formed by the drying of algal and seagrass tissues (dead or still alive) at the soil surface (Figs. $3 b$ and d). When very thin (few millimetres), the layer resembles to a Crusto system (Fig. 7). The algal component of this layer can be reactivated by incoming water or begins a process of decomposition as dead organic matter. It never gives way to a real Crusto system.

Organic and/or organic-mineral horizons $\mathrm{OA}=$ anaOA. Organic and/or organic-mineral horizon $(\mathrm{anaOA})=$ [ana = anaerobic, from Greek an (without), aer (air) and bios (life)] organic and/or organic-mineral horizon and formed by the deposition of organic and mineral particles suspended in water. Never emerged OA horizon. Plant roots possible (seagrasses). First phases of biological formation of sea and ocean floors, river beds. They can show even zoological activity due to benthic organisms (crustaceans, molluscs and aquatic worms). Possible in Aqueous systems over an anaA horizon (detailed in Humusica 2, article 12); specific to Para Anaero humus system (detailed in Humusica 2, article 13).

Organic-mineral horizons $\mathrm{A}=$ anaA. Organic-mineral horizon (anaA) = [ana =anaerobic, from Greek an (without), aer (air) and bios (life)] organic-mineral horizon and formed by the deposition and transformation of organic and mineral particles suspended in water. Never emerged A horizon. Plant roots possible (seagrasses). Iron oxides always in reduced greyish/greenish form $\left(\mathrm{Fe}_{2} \mathrm{O}_{3}\right)$. However, root and burrow linings may show red orange iron oxides. Slow process of anaerobic biotransformation of organic matter in place. They can show even zoological activity due to benthic organisms (crustaceans, molluscs and aquatic worms). When the volume of mineral particles estimated by the naked eye in fresh samples is larger than $90 \%$ of the horizon volume, the horizon is 
labelled anaAC. Generated by the evolution of an anaOA horizon. Sea and ocean floors, large river beds.

Remark the Munsell colour (Fig. 12) of the mineral matrix of anaA and gA is a useful tool for distinguishing these horizons:

- anaA shows $B=B$ Blue, $G=$ Green, or $B-G, Y=$ Yellow, or $G Y$ hue colours. Munsell colours - hue value/chroma - of some common anaA (Table. 1, Fig. 12): 10B 2/4; 10B 3/1; 5BG 2.5/1; 5BG 4/1; 10GY 4/1);

- gA shows $R=R e d, Y=Y e l l o w$ or $Y-R$ hue colours (Munsell colours of some common gA: 10YR $7 / 2 ; 10$ YR $6 / 1 ; 10 Y R$ 4/1; 2.5 Y $2.5 / 1 ; 2.5 Y 4 / 2 ; 2.5 Y 5 / 1)$.

Table 1 reports the dominant Munsell soil colours of diagnostic horizons recorded in Aqueous Tidal and Subtidal profiles.

\subsection{First attempt of classification}

We label as Aqueous all humus systems and forms developing in marine nearshore tidal and subtidal contexts. The following diagnostic horizons are observed in field: anaA, anaAC. In addition it is possible to observe hydromorphic $\mathrm{gA}$ and gO horizons ( $\mathrm{gOL}, \mathrm{gOF}, \mathrm{gOH}$ ), Histic anA and $\mathrm{H}$ horizons. These humus systems and forms generally characterize salty seasides.

Organic gOL, gOF, gOH horizons can contain algal litter. The organic-mineral anaA horizon is often stratified, showing different colours and a variable content in organic matter. The layers are numbered from top to bottom using $1,2 \ldots . n$ progressive numbers (example: anaA1 or gA1, anaA2 or gA2, anaA3 or gA3...).

The presence of the "anaA" horizon is mandatory for assigning the profile to an Aqueous system. The only presence of an anaOA horizon is not sufficient because in this case the profile could belong to a Para Anaero system (Humisica 2, article 13).

When the fresh volume of a horizon sample observed by the naked eye contains more than $90 \%$ of mineral particles, the horizon is labelled anaAC.

Intertidal Tidal system has been separated from undertidal Subtidal system.

In Tidal system, Redoxitidal and Reductitidal humus forms have been identified.

At present the Subtidal system is still unknown and a single Eusubtidal humus form is described (Table 2).

In gA horizons of Redoxitidal humus forms, orange $\left(\mathrm{Fe}_{2} \mathrm{O}_{3}\right)$ YR references dominate. On the contrary, in anaA horizons of Eusubtidal humus form ( $\mathrm{Fe}_{2} \mathrm{O}_{2}$ or black organic matter) $\mathrm{GY}, \mathrm{B}$ or $\mathrm{BG}$ are present and $Y R$ is absent. In Reductitidal profiles both reddish and grey colours are well present, even if the grey colour, indicating Fe reduction, dominates. 


\subsection{Crusto, Mull, and Moder as prefixes}

In tidal environments, we propose to use Crusto, Mull or Moder as prefixes in the following cases:

- Crusto: presence of aqueous litter laying on rock or mineral horizons without other humus horizons;

- Mull: presence of anecic or endogeic earthworms;

- Moder: presence of arthropods or epigeic earthworms that can be associated to the origin of the gA horizon, respectively. Following this rule, the humus profile under Posidonia (Fig. 8) can be classified as Crusto Redoxitidal, while humus formed under Juncus, Sarcocornia and Limonium in Figure 9 can be easily classified as Mull Redoxitidal; the profile under Juncus in Figures 8 and 9 and the one with algal litter in Figure 10 can be easily classified as Moder Redoxitidal.

- Mor as prefix is never used because a system switches to Histic conditions in case of absence of zoological activity.

\subsection{Final remarks}

- Generally, daily tides correspond to Aqueous systems but in this proposal Aqueous humus systems are confined to salty seaside and transitional environments (lagoons, estuaries). In fresh water prefixes Hydro and Terrestrial, or Epihisto and Histic references are preferable. However, sweet water tides are substantial in many countries (e.g. The Netherlands), and for the definition of Aqueous systems it will be necessary to evaluate whether the most important factor is the duration/periodicity of submersion or the presence of salt in water. The point is still under discussion and needs further investigations.

- It is possible to distinguish only three very simple categories: never submerged (affected or not by saline water intrusion; in coastal plain areas, salinity can affect both soil quality and agricultural productivity), periodically submerged (from saline to sweet water, in gradual range) and always submerged systems (from saline to sweet water, in gradual range). Terrestrial systems are never submerged or only a few days per year. Periodically submerged systems correspond to a very large range of situations: a) Hydro Terrestrial systems (submerged a few days till a few months per year); b) Epihisto Histic systems (submerged a few months till 5-7 months per year); c) Histic systems (submerged more than 6 months per year); d) Tidal Aqueous (submerged a few months till 11 months per year). Subtidal Aqueous systems are always submerged, by definition; Histic systems can belong to this category too, in case of slowly increasing water table and peat formation. Tidal systems have a very peculiar regime. Although in all other periodically submerged systems submersion lasts for long periods, in tidal systems water drains out of the soil in cycles that, depending on the height above the mean sea level, cause oxygen to re-enter the larger pores every $6-23 \mathrm{~h}$. So 
we have soils that on a yearly average are submersed for many months per year, but which are at the same time exposed to oxygen every day. This makes a big difference on the decomposition rates.

- The boundary between Aqueous and Terrestrial, or Epihisto and Histic references is difficult to trace for certain. Many kinds of active tidal flats exist. Examples: areas more or less submerged by floods outside of Dutch dikes or dunes; daily submerged areas even if without semi-terrestrial vegetation; flats or shoals only submerged during storm tides (with somewhat decalcified and desalinized topsoils) with some semi-terrestrial/tidal vegetation; shoals submerged only during extreme storm tides. In The Netherlands there are even sweet water tidal flats (with sweet water shoals that can be submerged daily) and sweet water flats submerged during storms from a certain direction (those are for example desalinized former arms of the sea like the "Ijsselmeer"). The same situations can be described even in Mediterranean areas and in many other places around the world.

- Generally, the presence of dominant Histic horizons (HF, HM, HS, anA) leads to Histic references or to their Epihisto intergrades. When former Terrestrial or Histic soils become permanently submerged or under the influence of daily tides, because of historical massive storm flood hazards or structural raising of the sea level, they correspond to submerged tidal systems and we can have Histic, Epihistic or Hydric horizons. The presence of dominant Terrestrial horizons ( $\mathrm{OL}, \mathrm{OF}, \mathrm{OH}, \mathrm{A}, \mathrm{AE}$ ) leads to Terrestrial references or to their Hydro intergrades but Hydro references never show completely anoxic reduced top mineral horizons, which can indeed occur in some cases.

- In stable water table conditions or in water without daily tides, Terrestrial Hydro, or Histic Epihisto, or Histic references are preferable. The presence of salty water has to be reported in the humus profile description.

- Halophile vegetation is more related to Aqueous than to Histic humus systems, but has to be used as indicator not as diagnostic character. In fact, many halophytes also grow in nonsaline soils, or thrive on road banks supplied with salt in winter for avoiding the formation of ice on the road or in salty areas along and between these roads. Moreover in semiarid parts of Europe, salty, brackish soils, or soils under the influence of saline groundwater are not uncommon.

- Archaeo systems are confined to very harsh environments (out of norm, e.g. high acidity, water pressure); Anaero systems strongly influenced by anaerobic bacteria that do not fit Histic or Aqueous systems (extreme environments such as sea beds or pioneer systems without finished horizons).

- Dried algae can form a thin layer (a few millimetres, Figure 7) at the soil surface, resembling a Crusto system. The algal component of this layer can be reactivated by incoming water or begin a process of decomposition as dead organic matter. It never gives way to a real Crusto system. Yet the formation of such layers has a strong influence on the underlying soil and has been classified as anaOL horizon.

\section{References}


Balestri, E., Vallerini, F., Lardicci, C., 2006. A qualitative and quantitative assessment of the reproductive litter from Posidonia oceanica accumulated on a sand beach following a storm. Estuar. Coast. Shelf Sci. 66, 30-34.

Balestri, E., Vallerini, F., Lardicci, C., 2011. Storm-generated fragments of the seagrass Posidonia oceanica from beach wrack: a potential source of transplants for restoration. Biol. Conserv. $144,1644-1654$.

Barko, J.W., Gunnison, D., Carpenter, S.R., 1991. Sediment interactions with submersed macrophyte growth and community dynamics. Aquat. Bot. 41, 41-65.

Boudouresque, C.F., Bernard, G., Bonhomme, P., Charbonnel, E., Diviacco, G., Meinesz, A., Pergent, G., Pergent-Martini, C., Ruitton, S.T.L., 2012. Protection and Conservation of Posidonia Oceanica Meadows. RAMOGE and RAC/SPA Publisher, Tunis. Available at: http://racspa.org/sites/default/files/doc vegetation/ramoge en.pdf.

Boudouresque, C.F., Jeudy de Grissac, A., 1983. L’herbier à Posidonia oceanica en Méditerranée: les interactions entre la plante et le sédiment. J. Rech. Océanogr. 8, 99-122.

Bradley, M.P., Stolt, M.H., 2003. Subaqueous soil-landscape relationships in a Rhode Island estuary. Soil Sci. Soc. Am. J. 67, 1487-1495.

Bradley, M.P., Stolt, M.H., 2006. Landscape-level seagrass-sediment relations in a coastal lagoon. Aquat. Bot. 84, 121-128.

Brambilla, C., Caneva, G., De Marco, G., Mossa, L., 1982. Analisi fitosociologica della seriazone psammofila costiera nella Sardegna meridionale. Ann. Bot. 40, 69-96.

Burdige, D.J., 2006. Geochemistry of Marine Sediments. Princeton University Press, Princeton.

Cardona, L., García, M., 2008. Beach-cast seagrass material fertilizes the foredune vegetation of Mediterranean coastal dunes. Acta Oecol. 34, 97-103.

Chessa, L.A., Fustier, V., Fernandez, C., Mura, F., Pais, A., Pergent, G., Serra, S., Vitale, L., 2000. Contribution to the knowledge of 'banquettes' of Posidonia oceanica (L.) Delile in Sardinia Island. Biol. Mar. Medit. 7, 35-38.

Cocco, S., Cardelli, V., Pedicini, S., et al., 2015. First observations on marine subaqueous soils in "Torre del Cerrano" marine protected area, Adriatic sea (Italy). EQA 19, 31-43.

Colombini, I., Chelazzi, L., 2003. Influence of marine allochthonous input on sandy beach communities. Oceanogr. Mar. Biol. 41, 115-159.

Colombini, I., Mateo, M.Á., Serrano, O., Fallaci, M., Gagnarli, E., Serrano, L., Chelazzi, L., 2009. On the role of Posidonia oceanica beach wrack for macroinvertebrates of a Tyrrhenian sandy shore. Acta Oecol. 35, 32-44.

De Falco, G., Simeone, S., Baroli, M., 2008. Management of beach-cast Posidonia oceanica seagrass on the Island of Sardinia (Italy, Western Mediterranean). J. Coastal Res. 24 (supplement 4C), 69-75. 
Defeo, O., McLachlan, A., Schoeman, D.S., Schlacher, T.A., Dugan, J., Jones, A., Lastra, M., Scapini, F., 2009. Threats to sandy beach ecosystems: a review. Estuar. Coast. Shelf Sci. 81, 1-12.

De Groot, R., Brander, L., Van der Ploeg, S., Costanza, R., Bernard, F., Braat, L., Christie, M., Crossman, N., Ghermandi, A., Hein, L., Hussain, S., Kumar, P., McVittie, A., Portela, R., Rodriguez, L.C., Ten Brink, P., Van Beukering, P., 2012. Global estimates of the value of ecosystems and their services in monetary units. Ecosyst. Serv. 1, 50-61.

Del Vecchio, S., Jucker, T., Carboni, M., Acosta, A.T.R., 2017. Linking plant communities on land and at sea: the effects of Posidonia oceanica wrack on the structure of dune vegetation. Estuar. Coast. Shelf Sci. 184, 30-36.

Del Vecchio, S., Marbà, N., Acosta, A., Vignolo, C., Traveset, A., 2013. Effects of Posidonia oceanica beach-cast on germination, growth and nutrient uptake of coastal dune plants. PLoS ONE 8(7), e70607.

Demas, G., Rabenhorst, M.C., 1999. Subaqueous soils: pedogenesis in a submersed environment. Soil Sci. Soc. Am. J. 63, 1250-1257.

Demas, G.P., Rabenhorst, M.C., 2001. Factors of subaqueous soil formation: a system of quantitative pedology for submersed environments. Geoderma 102, 189-204.

Demas, G.P., Rabenhorst, M.C., Stevenson, J.C., 1996. Subaqueous soils: a pedological approach to the study of shallow-water habitats. Estuaries 19, 229-237.

Dent, D.L., Pons, L.J., 1995. A world perspective on acid sulphate soils. Geoderma 67, 263-276.

Descostes, M.I., Beaucaire, C.A., Mercier, F.L., Savoye, S., Sow, J., Zuddas, P., 2002. Effect of carbonate ions on pyrite $\left(\mathrm{FeS}_{2}\right)$ dissolution. Bull. Soc. Géol. Fr. 173, 265-270.

Diaz-Almela, E., Marbà, N., Àlvarez, E., Balestri, E., Ruiz-Fernández, J.M., Duarte, C.M., 2006. Patterns of seagrass (Posidonia oceanica) flowering in the western Mediterranean. Mar. Biol. 148, 723-742.

Dodla, S.K., Wang, J.J., Delaune, R.D., 2012. Characterization of labile organic carbon in coastal wetland soils of the Mississippi River deltaic plain: relationships to carbon functionalities. Sci. Total Environ. 435-436, 151-158.

Ellis, J., Cummings, V., Hewitt, J., Thrush, S., Norkko, A., 2002. Determining effects of suspended sediment on condition of a suspension feeding bivalve (Atrina zelandica): results of a survey, a laboratory experiment and a field transplant experiment. J. Exp. Mar. Biol. Ecol. 267, 147174.

Erich, E., Drohan, P.J., 2012. Genesis of freshwater subaqueous soils following flooding of a subaerial landscape. Geoderma 179/180, 53-62.

Ewel, K.C., Cressa, C., Kneib, R.T., et al., 2001. Managing critical transition zones. Ecosystems 4, 452460.

Fanning, D.S., Fanning, M.C.B., 1989. Soil: Morphology, Genesis, and Classification. Wiley, New York. 
Fenchel, T.M., Riedl, R.J., 1970. The sulfide system: a new biotic community underneath the oxidized layer of marine sand bottoms. Mar. Biol. 7, 255-268.

Ferronato, C., 2015. Water, sediment and soil physicochemical interaction in freshwater, brackish and saline systems. PhD Thesis, University of Bologna.

Ferronato, C., Contin, M., De Nobili, M., Falsone, G., Pellegrini, E., Vianello, G., Vittori Antisari, L., 2015. Soil hydromorphism in two saline and brackish system: classification, indicators and pedogenetic processes. EQA 19, 17-30.

Ferronato, C., Falsone, G., Natale, M., Zannoni, D., Buscaroli, A., Vianello, G., Vittori Antisari, L., 2016. Chemical and pedological features of subaqueous and hydromorphic soils along a hydrosequence within a coastal system (San Vitale Park, Northern Italy). Geoderma 265, 141-151.

Fossing, H., Jorgensen, B., 1989. Measurement of bacterial sulfate reduction in sediments: evaluation of a single-step chromium reduction method. Biogeochemistry 8, 205-222.

Gedan, K.B., Kirwan, M.L., Wolanski, E., Barbier, E.B., Silliman, B.R., 2010. The present and future role of coastal wetland vegetation in protecting shorelines: answering recent challenges to the paradigm. Clim. Change 106, 7-29.

Gedroiz, K.K., 1927. Soil-absorbing complex and the absorbed soil cations as a basis of genetic soil classification. Nossov Agr. Expt. Sta. Paper 38, 1-29 (translation by S.A. Waksman in Papers on soil reaction, 1912-25).

Génin, J.M.R., Bourrié, G., Trolard, F., Abdelmoula, M., Jaffrezic, A., Refait, P., Maitre, V., Humbert, B., Herbillon, A., 1998. Thermodynamic equilibria in aqueous suspensions of synthetic and natural $\mathrm{Fe}(\mathrm{II})-\mathrm{Fe}$ (III) green rusts: occurrences of the mineral in hydromorphic soils. Environ. Sci. Technol. 32, 1058-1068.

Goñi, M.A., Teixeira, M.J., Perkey, D.W., 2003. Sources and distribution of organic matter in a riverdominated estuary (Winyah Bay, SC, USA). Estuar. Coast. Shelf Sci. 57, 1023-1048.

Halpern, B.S., Walbridge, S., Selkoe, K.A., Kappel, C.V., Micheli, F., d'Agrosa, C., Bruno, J.F., Casey, K.S., Ebert, C., Fox, H.E., Fujita, R., Heinemann, D., Lenihan, H.S., Madin, E.M.P., Perry, M.T., Selig, E.R., Spalding, M., Steneck, R., Watson, R., 2008. A global map of human impact on marine ecosystems. Science 319, 948-952.

Homann, P.S., Grigal, D.F., 1996. Below-ground organic carbon and decomposition potential in a field-forest glacial-outwash landscape. Biol. Fertil. Soils 23, 207-214.

Ince, R., Hyndes, G.A., Lavery, P.S., Vanderklift, M.A., 2007. Marine macrophytes directly enhance abundances of sandy beach fauna through provision of food and habitat. Estuar. Coast. Shelf Sci. 74, 77-86.

IPCC AR4 SYR, 2007. Climate Change 2007: Synthesis Report, Contribution of Working Groups I, II and III to the Fourth Assessment Report of the Intergovernmental Panel on Climate Change. IPCC, Geneva, Switzerland. 
IUSS Working Group WRB, 2006. World Reference Base for Soil Resources 2006. Food and Agriculture Organisation, Rome.

Ivanov, M.V., Yu, A., Reeburgh, M.S., Skyring, G.W., 1989. Interaction of sulphur and carbon cycles in marine sediments. In: Brimblecombe, P., Lein, A.Y. (Eds.), Evolution of the Global Biogeochemical Sulphur Cycle. Wiley, Chichester, pp 61-78.

Kao, S.J., Horng, C.S., Roberts, A.P., Liu, K.K., 2004. Carbon-sulfur-iron relationships in sedimentary rocks from southwestern Taiwan: influence of geochemical environment on greigite and pyrrhotite formation. Chem. Geol. 203, 153-168.

Kennish, M., 2001. Coastal salt marsh systems in the U.S.: a review of anthropogenic impacts. J. Coast. Res. 17, 731-748.

Krairapanond, N., DeLaune, R.D., Patrick, W.H., 1992. Distribution of organic and reduced sulfur forms in marsh soils of coastal Louisiana. Org. Geochem. 18, 489-500.

Kristensen, E., Rabenhorst, M.C., 2015. Do marine rooted plants grow in sediment or soil? A critical appraisal on definitions, methodology and communication. Earth-Sci. Rev. 145, 1-8.

Larkum, A.W.D., Orth, R.J., Duarte, C.M., 2006. Seagrasses: Biology, Ecology and Conservation. Springer, Dordrecht.

Lotze, H.K., Lenihan, H.S., Bourque, B.J., Bradbury, R.H., Cooke, R.G., Kay, M.C., Kidwell, S.M., Kirby, M.X., Peterson, C.H., Jackson, J.B.C., 5, 2006. Depletion, degradation, and recovery potential of estuaries and coastal seas. Science 312, 1806-1809.

McGranahan, G., Balk, D., Anderson, B., 2007. The rising tide: assessing the risks of climate change and human settlements in low elevation coastal zones. Environ. Urban. 19, 17-37.

McLachlan, A., Elliot, I.G., Clarke, D.J., 1985. Water filtration through reflective microtidal beaches and shallow sublittoral sands and its implication for an inshore ecosystem in Western Australia. Estuar. Coast. Shelf Sci. 12, 267-278.

Moretti, D., Combatti, B., Staatarchiv, O., 2015. I progetti Life in laguna di Venezia e nell'alto Adriatico. Consiglio Regionale del Veneto, Venice.

Mossa, L., Curreli, F., Fogu, M.C., 2000. La vegetazione degli habitats terrestri della riserva marina protetta di Capo Carbonara (Sardegna sud-orientale). Rend. Sem. Fac. Sci. Univ. Cagliari 70, 164-185.

Mossa, L., Scrugli, A., Milia, G., 1984. Flora e vegetazione dell'Isola di Mal di Ventre (Sardegna centrooccidentale). Rend. Sem. Fac. Sci. Univ. Cagliari 54, 119-142.

Ponnamperuma, F., 1972. The chemistry of submerged soils. Adv. Agron. 24, 29-95.

Rabenhorst, M.C., Stolt, M.H., 2012. Subaqueous soils: pedogenesis, mapping, and applications. In: Lin, H. (Ed.), Hydropedology: Synergistic Integration of Soil Science and Hydrology. Academic Press, Waltham, pp. 173-204. 
Reddy, R.K., DeLaume, D., 2008. Biochemistry of Wetlands: Science and Applications. CRC Press, Boca Raton.

Richardson, J.L., Vepraskas, M.J., Craft, C.B., 2001. Wetland Soils: Genesis, Hydrology, Landscapes, and Classification. Lewis, Boca Raton.

Roden, E.E., 2004. Analysis of long-term bacterial vs. chemical Fe(III) oxide reduction kinetics. Geochim. Cosmochim. Acta 68, 3205-3216.

Roig, F.X., Martín-Prieto, J.A., Comas, E., Rodríguez-Perea, A., 2006. Space-time analysis (1956-2004) of human use and management of the beach-dune systems of Menorca (Balearic Islands, Spain). J. Coast. Res. 48 (Special Issue), 107-111.

Santín, C., González-Pérez, M., Otero, X.L., Álvarez, M.Á, Macías, F., 2009. Humic substances in estuarine soils colonized by Spartina maritima. Estuar. Coast Shelf Sci. 81, 481-490.

Schaetzl, R.J., Anderson, S., 2005. Soils: Genesis and Geomorphology. Cambridge University Press, Cambridge.

Servera, J., Martín-Prieto, J.A., Rodríguez-Perea, A., 2002. Forma y dinámica de las acumulaciones de Posidonia oceanica: su papel como elemento protector de la playa subáerea. In: PérezGonzález, A., Vegas, J., Machado, M.J. (Eds.), Aportaciones a la Geomorfología de España en el incicio del Tercer Milenio. Instituto Geológico Minero, Madrid, pp. 363-369.

Silvestri, S., Defina, A., Marani, M., 2005. Tidal regime, salinity and salt marsh plant zonation. Estuar. Coast Shelf Sci. 62, 119-130.

Simonson, R.W., 1959. Outline of a generalized theory of soil genesis. Soil Sci. Soc. Am. Proc. 23, 152156.

Soil Survey Staff, 2010. Keys to Soil Taxonomy, $11^{\text {th }}$ ed. United States Department of Agriculture, Natural Resources Conservation Service, Washington, D.C.

UNEP, 2006. Marine and Coastal Ecosystems and Human Well-Being: a Synthesis Report Based on the Findings of the Millennium Ecosystem Assessment. United Nations Environment Programme, Nairobi.

Vittori Antisari, L., De Nobili, M., Ferronato, C., Natale, M., Pellegrini, E., Vianello, G., 2016. Hydromorphic to subaqueous soils transitions in the central Grado lagoon (Northern Adriatic Sea, Italy). Estuar. Coast Shelf Sci. 173, 39-48.

Vodyanitskii, Y.N., Shoba, S.A., 2014. Disputable issues in interpreting the results of chemical extraction of iron compounds from soils. Eurasian Soil Sci. 47, 573-580.

Wong, J.X.W., Colen Van, C., Airoldi, L., 2015. Nutrient levels modify saltmarsh responses to increased inundation in different soil types. Mar. Environ. Res. 104, 37-46. 


\section{Figure captions}

Fig. 1. Schematic representation of the marine nearshore system with the definition of tidal areas. Source: Kristensen and Rabenhorst (2015).

Fig. 2. Schematic representation of the subaqueous soil classification in the Soil Taxonomy (a) and in the World Reference Base (b).

Fig. 3. Example of a soil catena in intertidal areas where the vegetation cover indicates soil hydromorphism ( $a$ and $b$ ) and detail of a subaqueous soil epipedon (Spartina maritima cover - c; Zostera noltii cover - d). Photos from Grado lagoon (Northern Italy) by C. Ferronato.

Fig. 4. Details of redoximorphic features in hydric and subaqueous soils: organic film around an organic fragment in decomposition (a) and black nodules and reddish mottling (b). Photos from Grado lagoon (Northern Italy) by C. Ferronato.

Fig. 5. Schematic representation of a tidal-subtidal soil catena with indication of a) texture and presence of redoximorphic features (reddish colors) and of b) matrix color. $\mathrm{S}=$ sandy; $\mathrm{SL}=$ sandy loam; LS = loamy sand; MK = muck; SILC = silty loamy sand; SIL = silty; SLC = silty clay loam; $\mathrm{CL}=$ clayey.

Fig. 6. Example of redoximorphic features around plant roots in intertidal soils. $\mathrm{O}_{2}$ diffusion from roots allows the formation of an oxic rhizosphere where $\mathrm{Fe}^{2+}$ is oxidized to $\mathrm{Fe}^{3+}$ and precipitates in reddish brown concretions. Photos from Grado lagoon by C. Ferronato.

Fig. 7. Examples of a) algal felt mats drying out at the soil surface of a saltmarsh bar after the end of a period of prolonged submergence, $b$ ) algal crust above sulfide accumulation and c) details of layered microalgal crust in saltmarshes of the northern Adriatic. Photos: a) and b) M. De Nobili, c) C. Ferronato.

Fig. 8. Example of zoological activity in hydric soils of the Grado and Marano lagoon (northern Adriatic sea): aboveground vegetation (a), fragmentation (b) and burial of organic residues and humic components by arthropods under a mixed vegetation of Juncus, Sarcocornia and Limonium (c). Photos by M. De Nobili.

Fig. 9. Example of zoological activity in hydric soils of the Grado and Marano lagoon (northern Adriatic sea): aboveground vegetation (a), surface litter (b) and burial of organic residues and humic components by annelids under a mixed vegetation of Juncus, Sarcocornia and Limonium (c). Photos by M. De Nobili.

Fig. 10. Example of zoological activity in hydric soils of the Grado and Marano lagoon (northern Adriatic sea): a) sloping channel bank (a), traces of zoogenic activity at the surface (b) and within the soil (c). The burrowing action of annelids and small crustaceans allows faster oxygen diffusion which causes oxidation and precipitation of iron. Photos by M. De Nobili.

Fig. 11. Poseidonia deposition in the Mediterranean coasts. Photos from Giorgino Beach, Cagliari (IT), by A. Vacca. 
Fig. 12. The Munsell colour system, showing: a circle of hues at value 5 and chroma 6 ; the neutral values from 0 to 10; and the chromas of purple-blue (5PB) at value 5. From Wikipedia https://en.wikipedia.org/wiki/Munsell color system, and Image 2007 Jacob Rus: CC BY-SA 3.0, http://commons. wikipedia.org/w/index.php?curid=1955750. 
Table 1

Munsell colours of Aqueous humus horizons. For colours, see Fig. 12 "N" letter refers to the value central, Neutral black -grey- white axis of the figure.

\begin{tabular}{|c|c|c|c|}
\hline \multirow[t]{2}{*}{ Horizons } & \multicolumn{2}{|l|}{ TIDAL } & \multirow{2}{*}{$\begin{array}{l}\text { SUBTIDAL } \\
\text { Eusubtidal }\end{array}$} \\
\hline & Redoxitidal & Reductitidal & \\
\hline $\mathrm{gO}$ & 10YR $2 / 1$ & 10YR $2.5 / 1$ & $5 G Y 3 / 1 ; N 2.5 / 1$ \\
\hline $\begin{array}{l}\text { gA1 or } \\
\text { anaA1 }\end{array}$ & $\begin{array}{l}\text { 10YR } 7 / 2 ; 10 Y R \\
4 / 1 ; 2.5 Y 2.5 / 1 ; \\
2.5 Y 4 / 2\end{array}$ & $\begin{array}{l}\text { 10YR } 5 / 2 ; 10 \text { Y } 3 / 1 ; \\
\text { N } 2.5 / 1 ; 10 Y 4 / 1 ; 5 Y \\
5 / 1 ; \text { N } 3 / 1\end{array}$ & $\begin{array}{l}10 B 2 / 4 ; 10 G Y 4 / 1 ; N \\
2.5 / 1\end{array}$ \\
\hline $\begin{array}{l}\text { gA2 or } \\
\text { anaA2 }\end{array}$ & 10YR 4/1 & N 2.5/1; 10Y 4/1 & 10B $3 / 1 ;$ N 5/1 \\
\hline $\begin{array}{l}\text { gA3 or } \\
\text { anaA3 }\end{array}$ & $\begin{array}{l}10 \text { YR } 6 / 1 ; 2.5 \text { Y } 5 / \\
1\end{array}$ & $\begin{array}{l}10 \text { YR } 4 / 2 ; \mathrm{N} 3 / 1 ; \mathrm{N} \\
7 / 1\end{array}$ & 5BG 2.5/1; 5BG 4/1 \\
\hline anaAC & N 5/1; N 6/1 & $\begin{array}{l}\text { N 7/1; } 10 Y 4 / 1 ; \mathrm{N} 4 / \\
1 ; 5 G 5 / 1\end{array}$ & $\begin{array}{l}\text { 5BG } 2.5 / 1 ; 5 \text { GY } 6 / 1 ; \\
\text { N 5/1; } 10 \text { GY } 3 / 1 ; \\
10 \text { GY } 4 / 1 ; 10 \text { GY } 8 / 1\end{array}$ \\
\hline
\end{tabular}




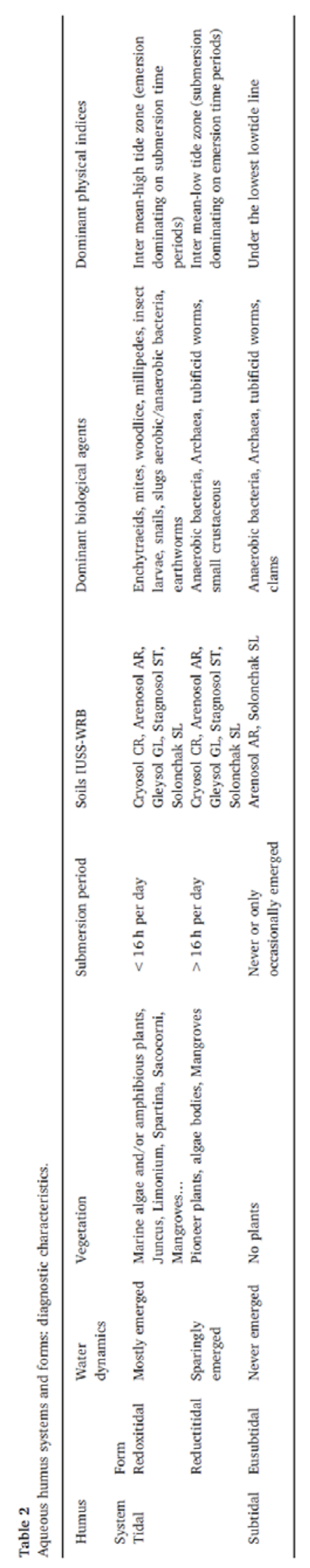


Marine Nearshore

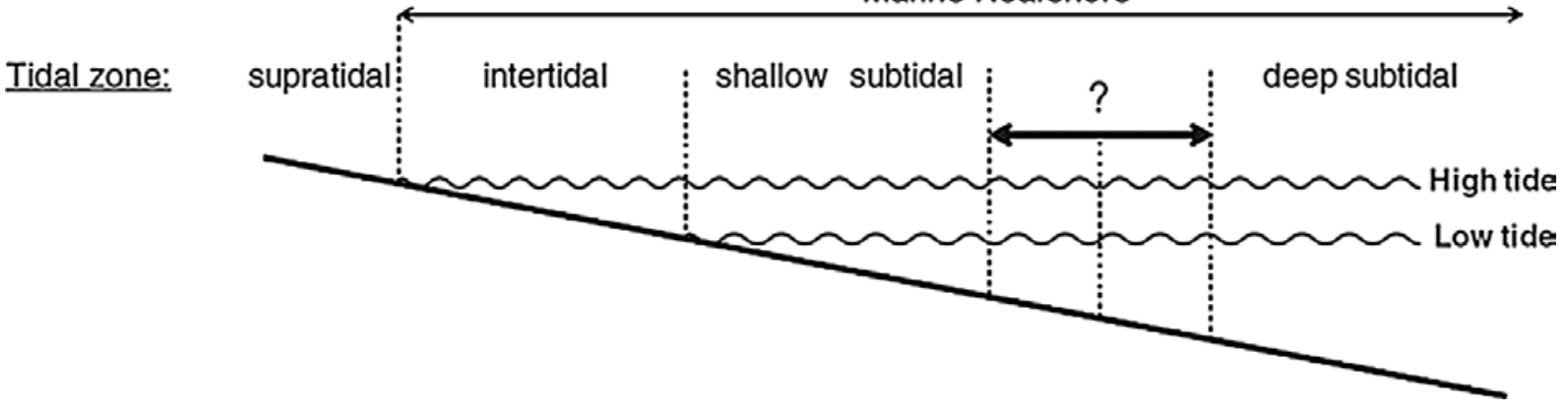

Fig. 1 
a

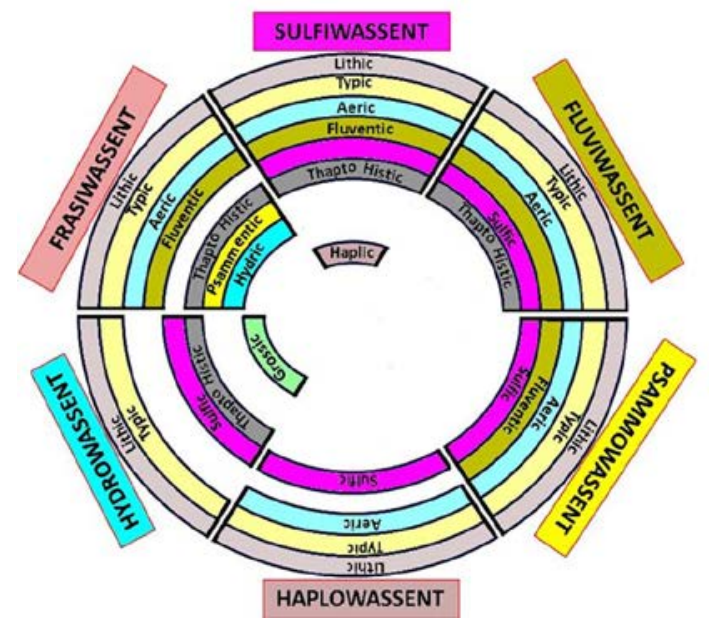

b

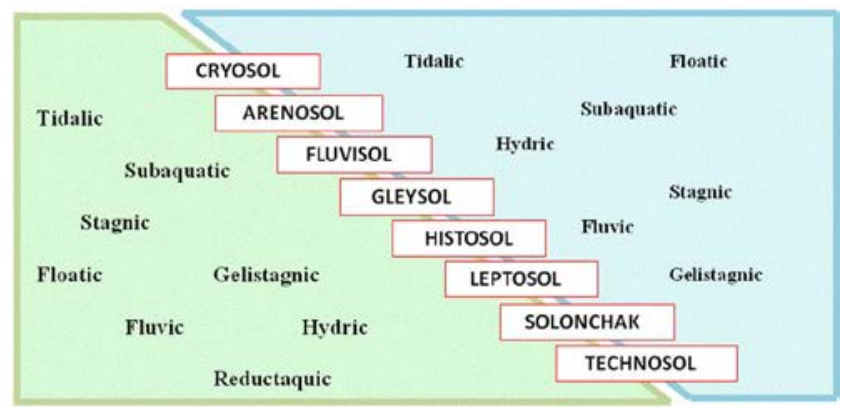

Fig. 2 
a

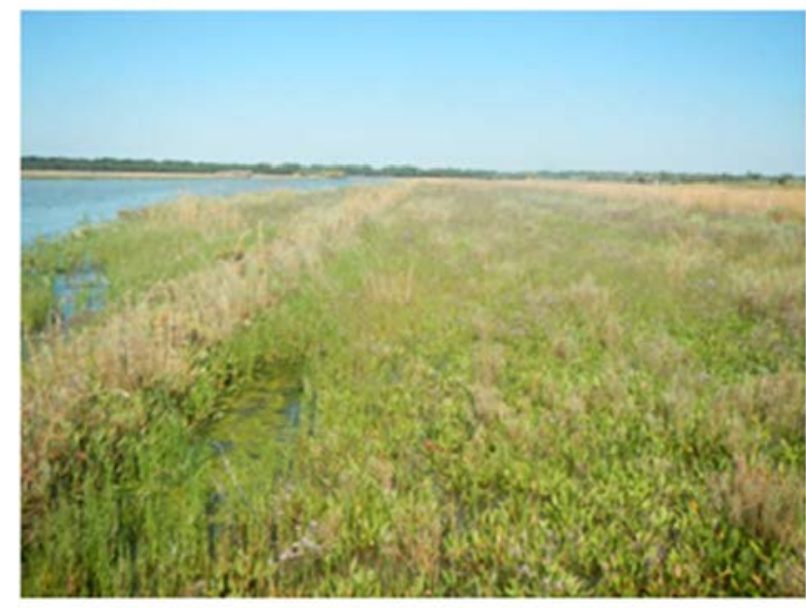

c

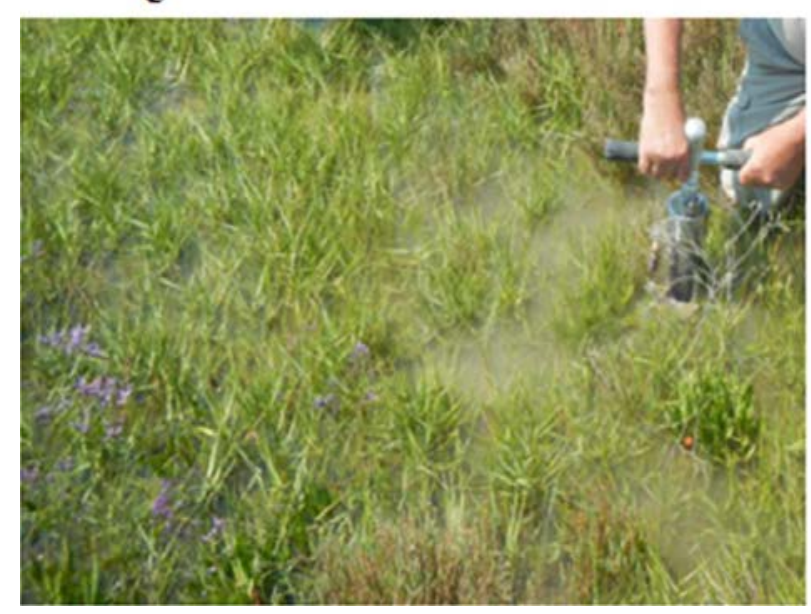

b
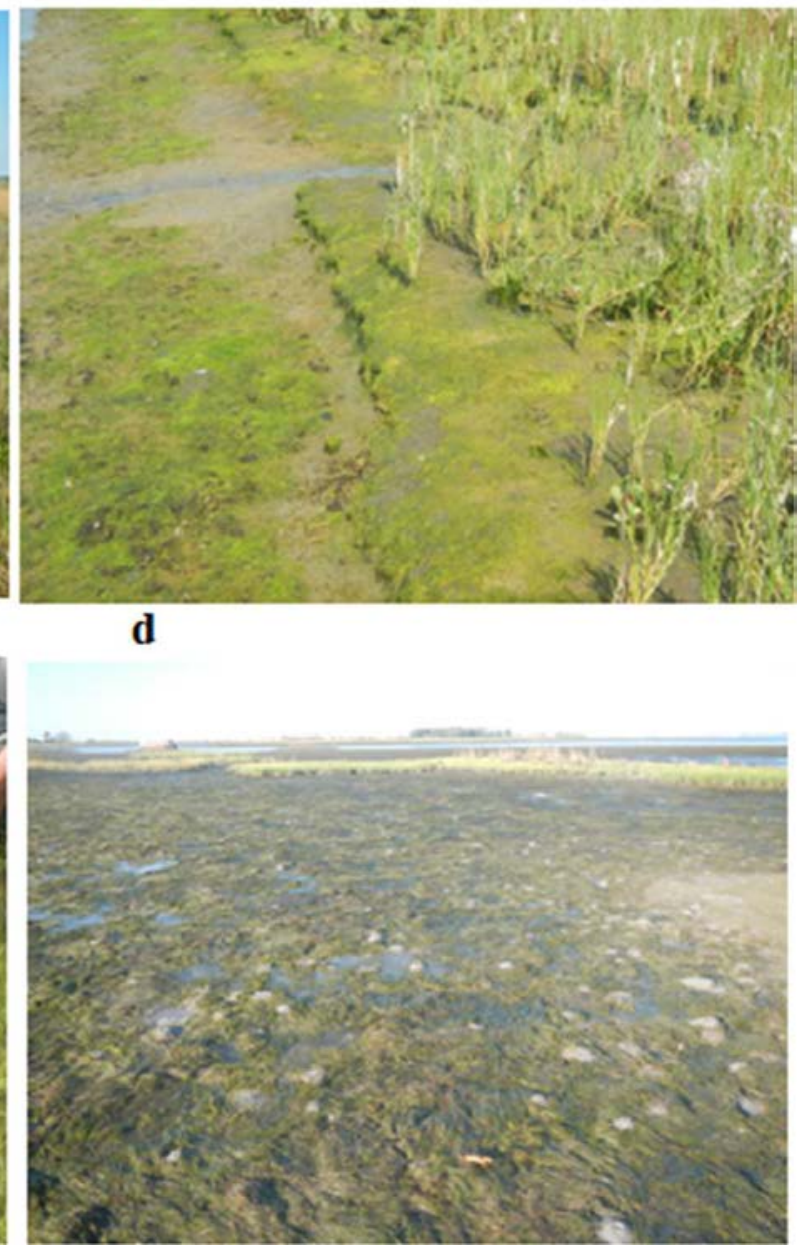

Fig. 3 
a

b

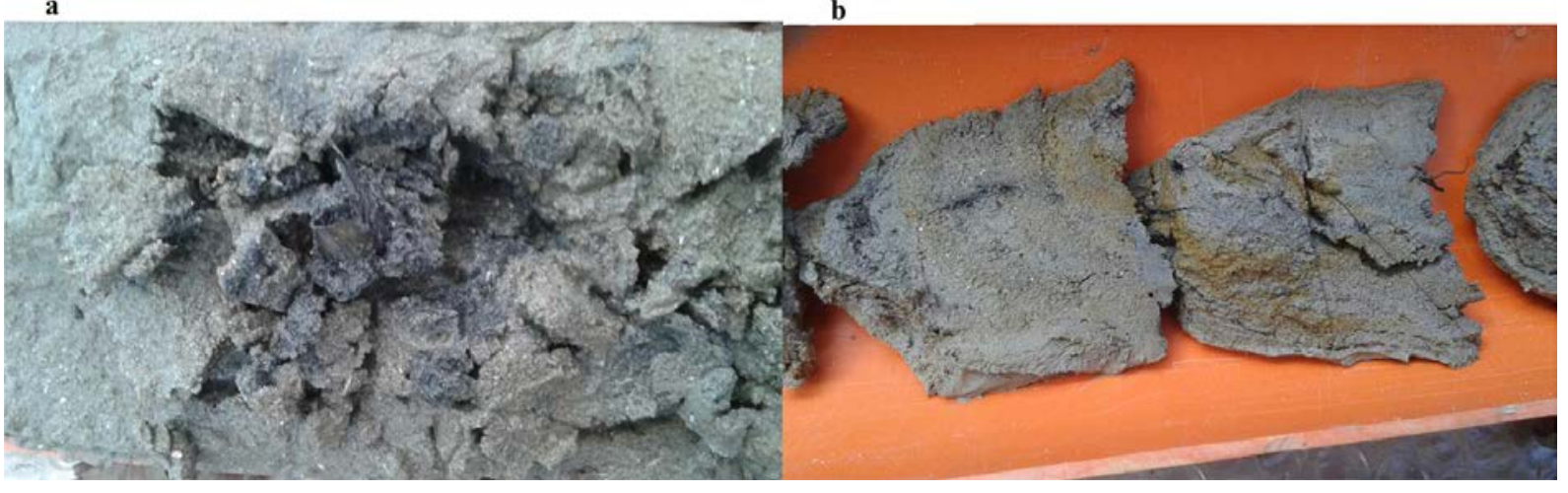

Fig. 4 

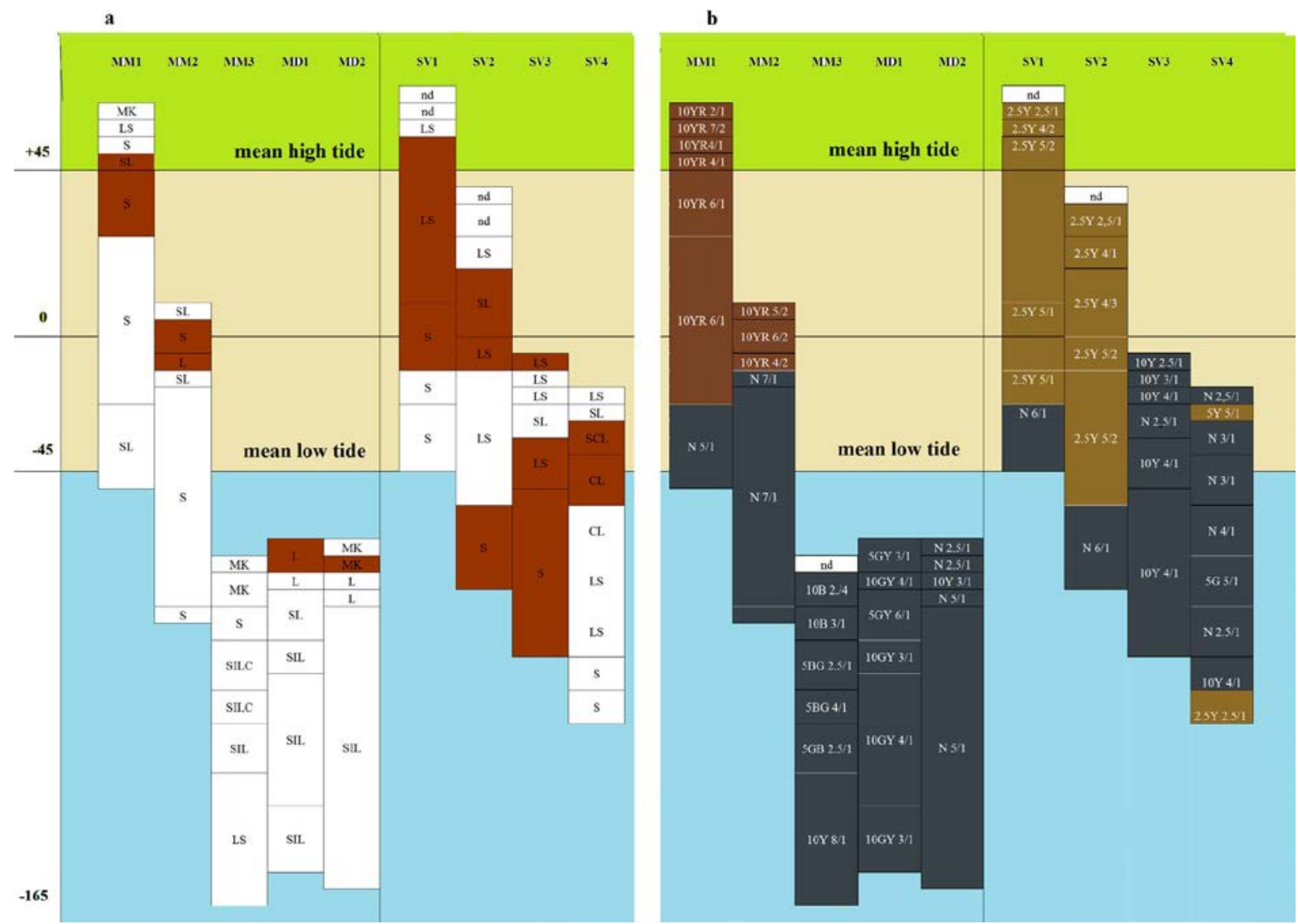

Fig. 5 


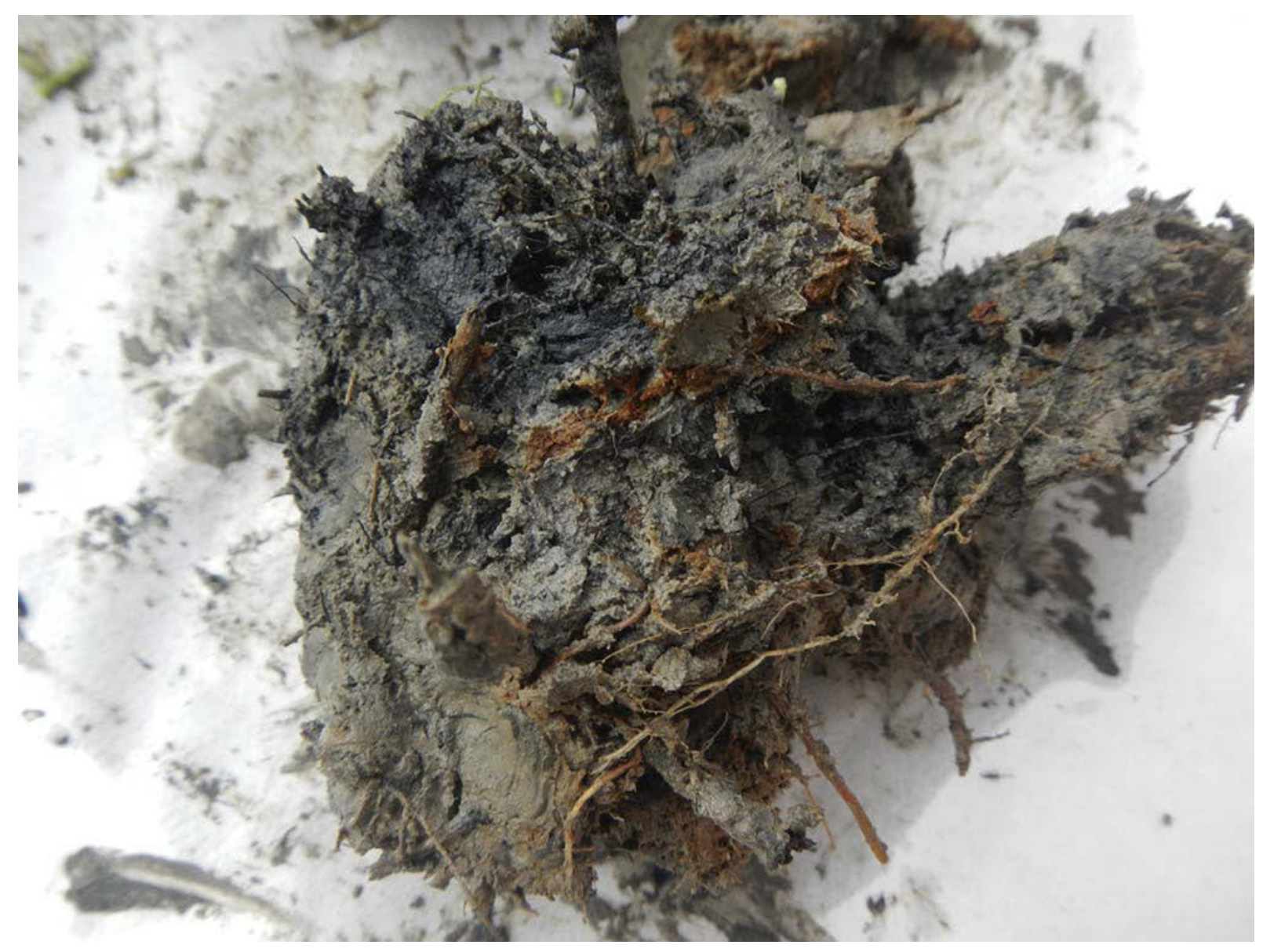

Fig. 6 


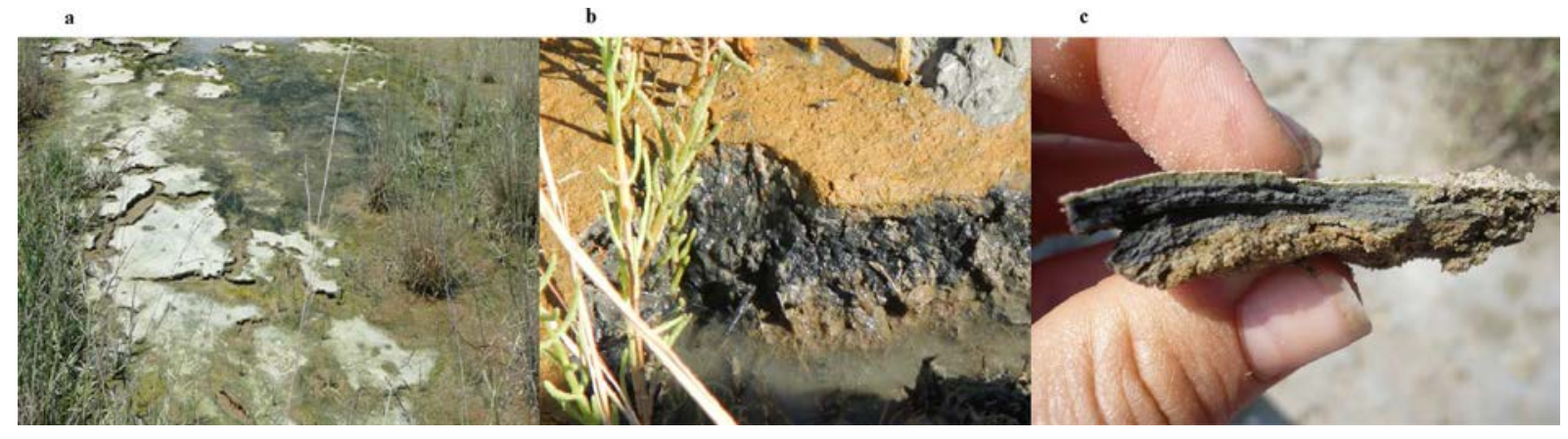

Fig. 7 
a

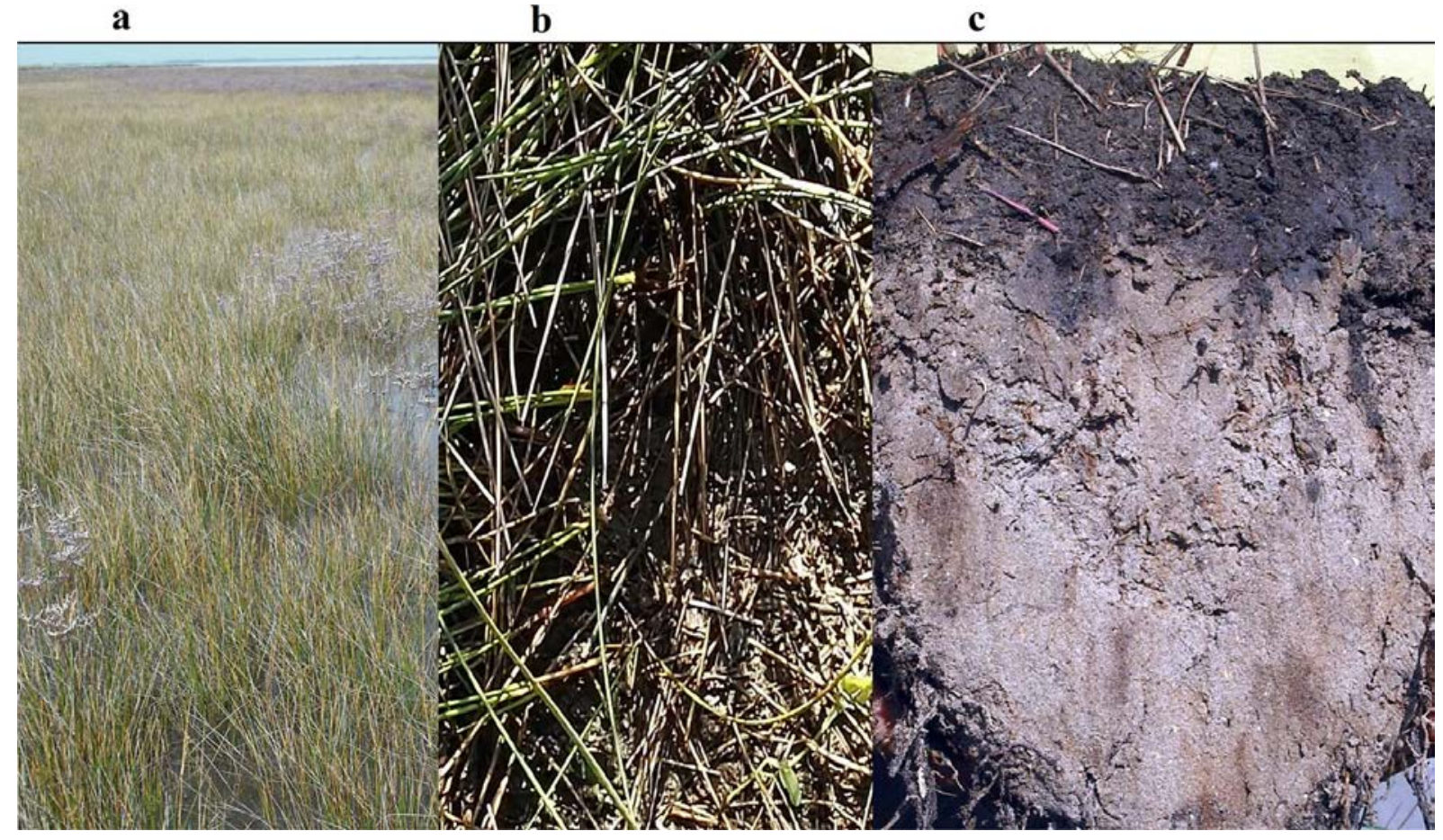

Fig. 8 
a

b

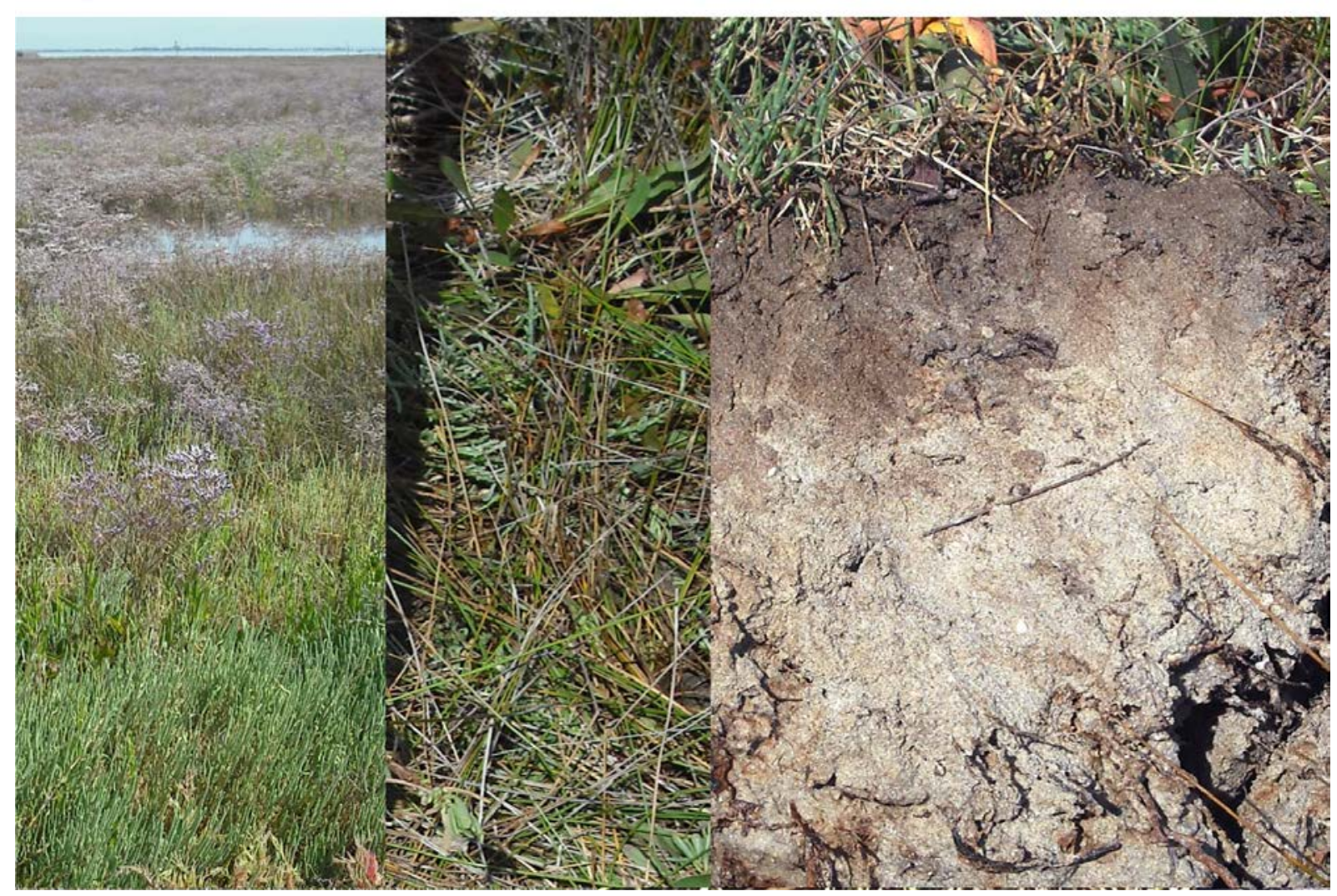

Fig. 9 


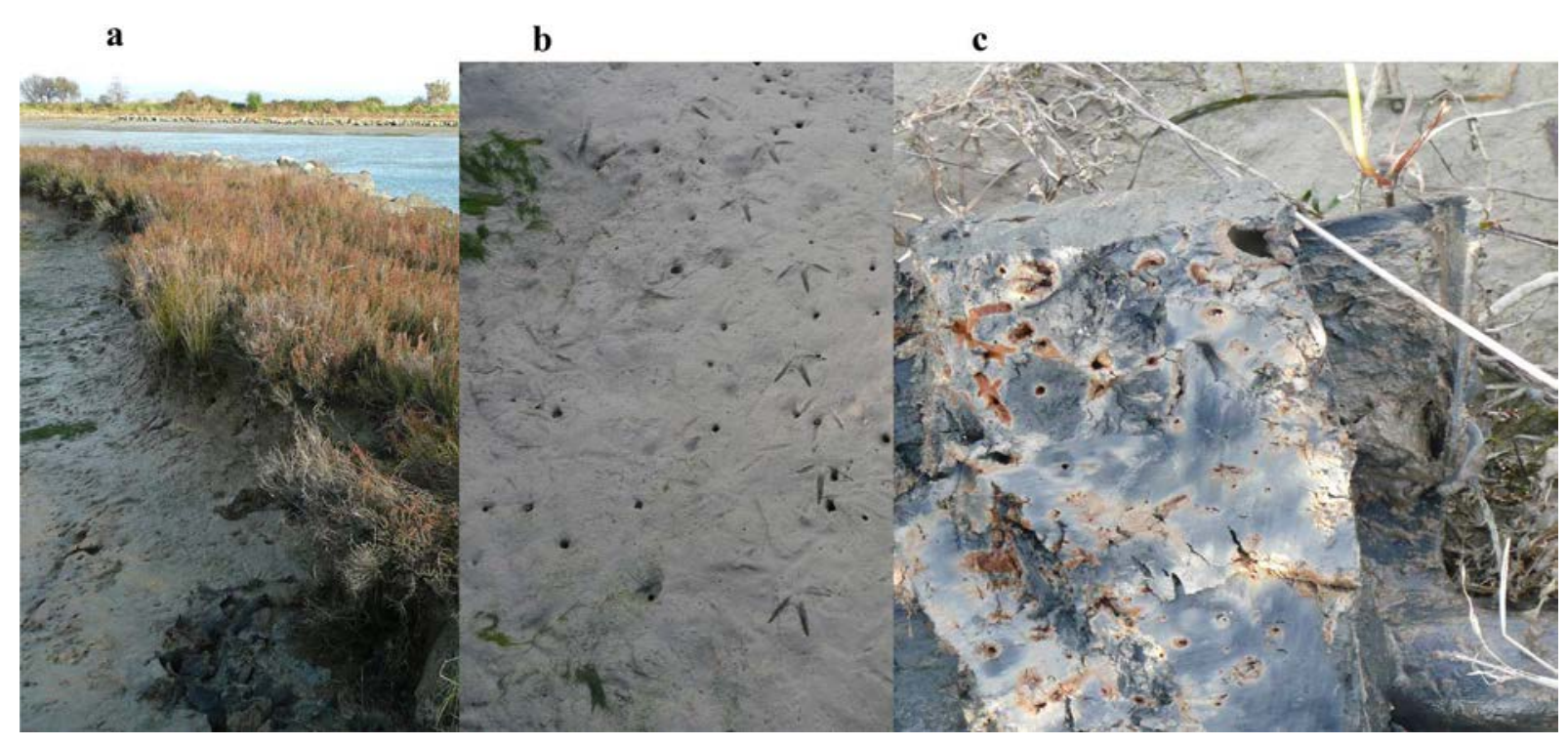

Fig. 10 


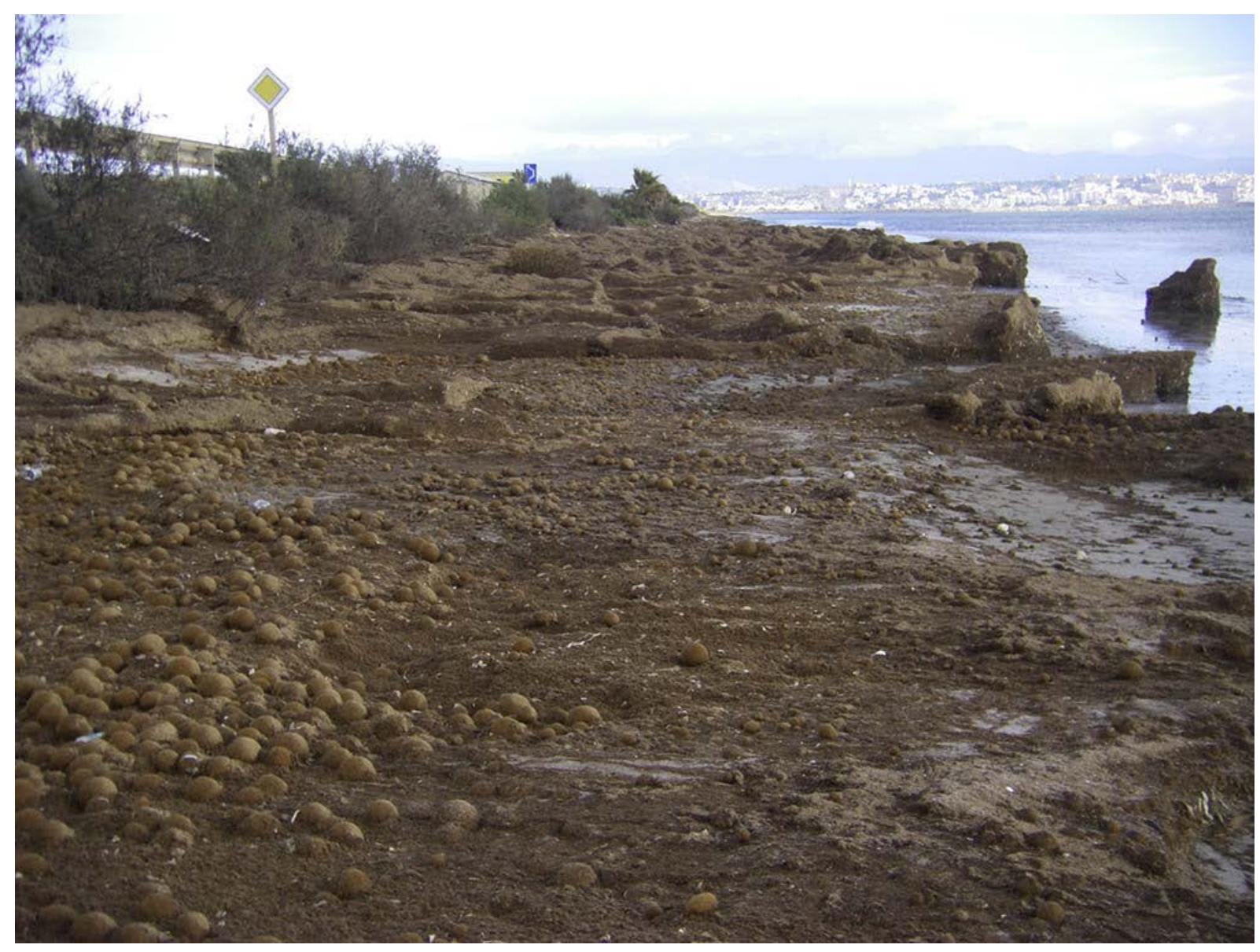

Fig. 11 


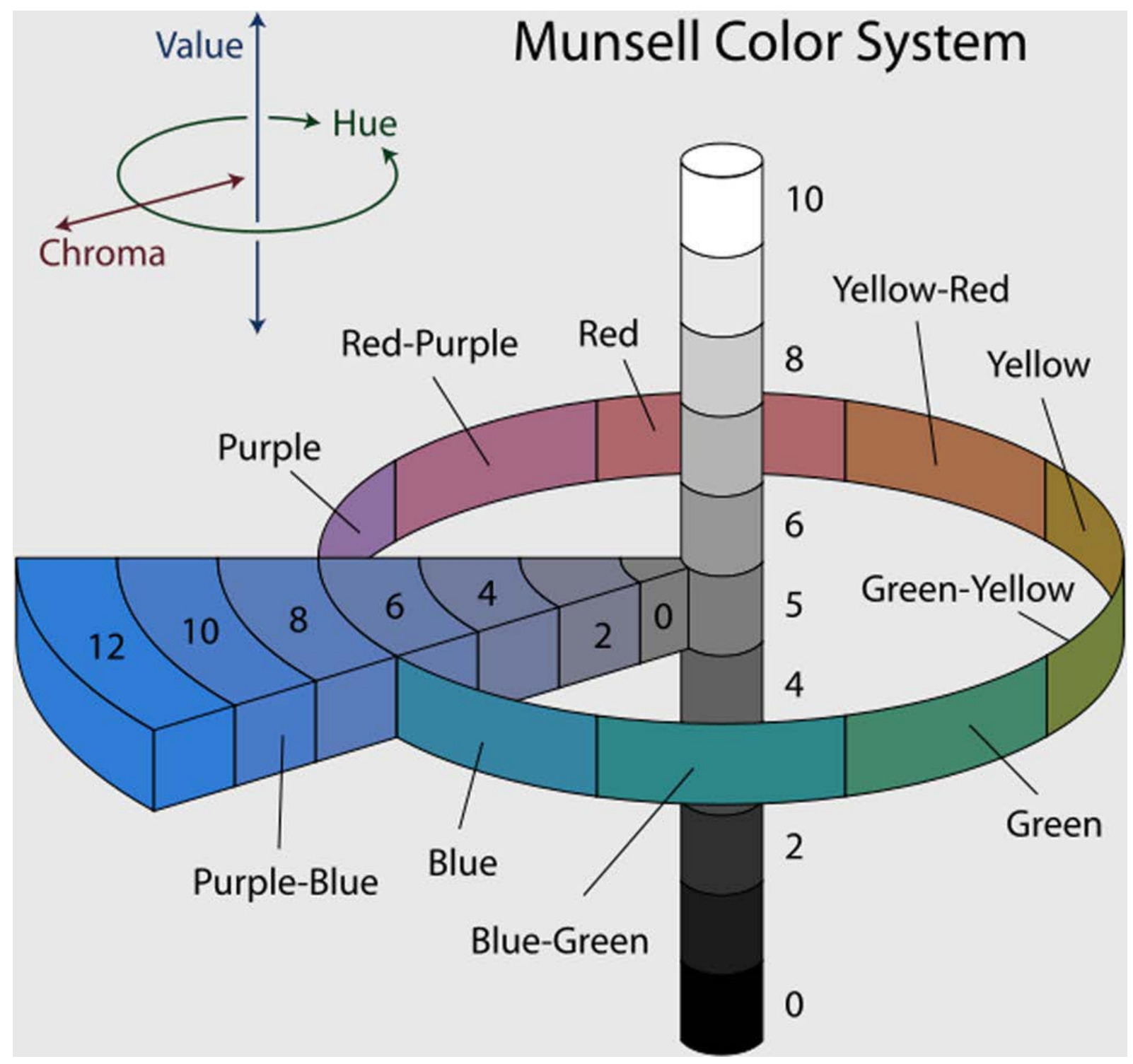

Fig. 12 